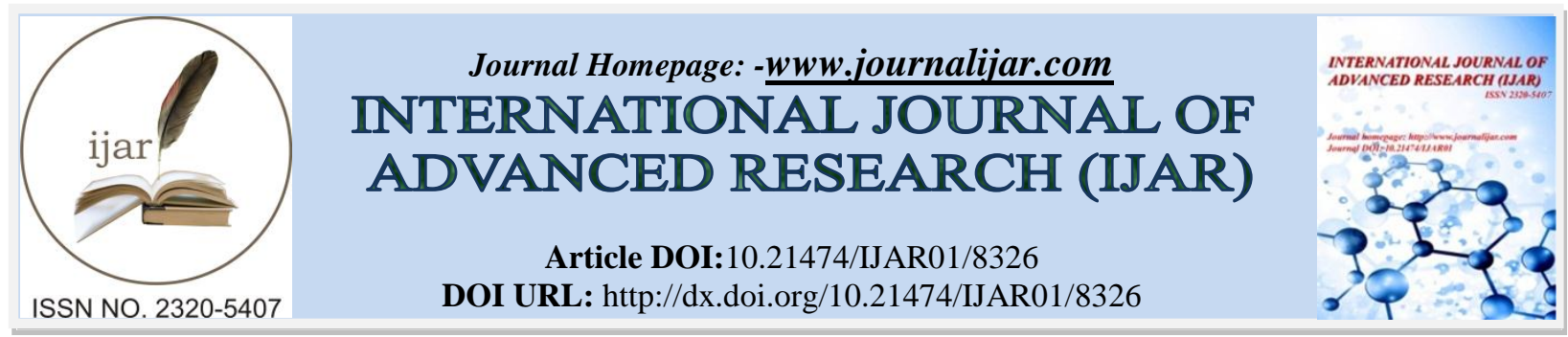

RESEARCH ARTICLE

\title{
IMPLICATIONS OF HUMAN RESOURCE ACCOUNTING ON HUMAN CAPITAL MEASUREMENT IN FINANCIAL REPORTS.
}

\author{
Abel aig. Asein, timothy a. Soetan and i.r. Akintoye. \\ Department of accounting, Babcock University, Ilisan-Remo, Nigeria.
}

\section{Manuscript Info}

Manuscript History

Received: 04 November 2018

Final Accepted: 06 December 2018

Published: January 2019

Key words:-

Human Resource Accounting, Human

Resource Measurement, Financial

Reports, Hidden values, Critical

Resource.

\section{Abstract}

Human capital creates value by coordinating and managing other capitals to achieve corporate goals. Although intangible, the human factor gives life to entities, creates harmonious environment for improved efficiency, effectiveness and economy in the use of corporate resources. Its usefulness to internal productivity and external goodwill are acknowledged in the literature. Its quality, expertise, experience, character and integrity are attributes sought after by providers of financial and other capitals. Economic benefits flow to the entity from human capital.

However, in corporate financial reports, human capital is not an element of the Statement of Financial Position or Balance Statement. Since financial values are not assigned to human resource like other assets, investment in and reward to human capital, which enhance its output, are expensed at the Income Statement level. This practice diminishes its status as the most critical resource of the organization as board chairmen often declare at annual general meetings.

Using secondary data, this study supports the findings of previous research works that the assignment of financial values and reflection of human resource in balance sheet, will raise shareholders' wealth and eliminate hidden values in financial reports.

Since human capital satisfies the criteria of identifiability and control by an entity set by IAS 38 for Intangible Assets, this study recommends that standard setters and policy makers should commence the process that will lead to the recognition of human capital in balance sheet.

Copy Right, IJAR, 2019. All rights reserved.

\section{Introduction:-}

All capitals are involved in the process of value creation in organisations. The factors of materials, machines and money are coordinated and managed by the human resource factor. The importance of the human factor was underscored by Roos, J., Roos, G., Dragonetti and Edvinsson (1997) when they described what is left of an organization as just the structural capital when all the employees have closed for the day and gone home. The factory structure, the information technology systems and the documented procedures will all lie idle and unproductive without the human factor. Even in this age of Artificial Intelligence, the human factor is still key. Sometimes described as intellectual capital, human resource defines the vision and the dream ticket which entails the

Corresponding Author:-Abel Aig. Asein.

Address:-Department of accounting, Babcock University, Ilisan-Remo, Nigeria. 
set of assets and strategies required to achieve set corporate goals. Thus, corporate entities exist because of the role and influence of the human resource.

Before employees are engaged, many of them have some skills and competences acquired through formal education, professional training and work-place experiences. The entity also invests in them through capacity building initiatives and exposure to tasks and opportunities that will further enhance their competences and productivity. These costs are expensed at the Income Statement level not because they do not add value but in conformity with age long accounting practice of matching cost and revenue developed when assets largely had physical existence. As a result, the information on how it changes in value over time is also lost to the board and stakeholders.

Human capital is an intangible asset which should not just be expensed because there are short and long term economic benefits that will flow to the entity through the new employees' skills and competence including the learning curve effect. Since new ideas demonstrate their values in the context of experience, cost incurred in personnel training and other capacity building initiatives ought to be capitalized as investments in human assets and reflected in balance sheets because of the expected future benefits. External users of the resultant financial statements will be better informed about the extent to which the entity's human capital increased or decreased during the reporting period (Andrade \& Sotomayor, 2011).

When McGregor(1960) wrote his treatise on the Human Side of Enterprise, he was persuaded that without the human angle particularly in terms of values, integrity, creativity, innovation and motivation, the business entities will be inactive, unproductive and devoid of the competitive spirit to create wealth for stakeholders. This man factor, according to him, must be properly managed to raise corporate productivity, efficiency and profitability. In this dynamic, knowledge-driven age, it is the human asset that defines an organization, its survival, growth, sustainability, legitimacy and goodwill. It is in this respect that Brooking (2010) in its Intellectual Capital Audit Method argues persuasively that intangible assets are now more important to high growth, high technology companies than tangible assets. In essence, tangible assets must be coupled with intangible assets for the corporate entity to grow and become valuable.

The importance of the human asset is not restricted to its internal usefulness for effective and efficient resource management. It is a source of confidence to external resource providers and in particular, financial institutions. The practice of unveiling the people behind an organization before credits are extended to them has become the norm rather than exception for financial institutions in Nigeria. Indeed, two of the Five C's for gauging the creditworthiness of potential borrowers in banking practices is the Character and Capacity of the persons behind the entity applying for a loan or credit facility. The quality and integrity of the human resource are parameters for assessing whether the credit facility will be properly managed or not. The recent corporate failures in USA, Europe, Asia and Africa point to the need to place greater premium on the human resource as it defines corporate prosperity or collapse.

Although it is an intangible asset, the human resource creates and adds value to enterprise. Notwithstanding its immense contributions in value creation, it is expensed as wages, salaries and other remunerations at the Income Statement level. The current generally accepted accounting practices discounts the human resource making it an ineligible item on the face of the balance sheet which captures the worth of an entity. This exclusion, which is in tandem with accounting standards (IAS 1: Presentation of Financial Statements), implies that the most important asset of the entity is not accounted for by persons in fiduciary capacities. Given this position, some schools of thought have noted that financial statements prepared without appropriate values assigned to the intangible asset of human resource will neither be true and fair nor will they satisfy the attributes of relevance and presentational faithfulness as fundamental qualitative characteristics of financial statements.

According to them, the absence of human resource accounting numbers in balance sheet "may result in distorted presentation of organisations' financial statements and the assessment of true organisations' performance could be misleading (Adebawojo, Enyi and Adebawo, 2015, p.46)". Here lies the need to give deserved attention to the place of the intangible asset of human resource in financial reporting through the embrace of Human Resource Accounting (HRA). For, according to Oke (2010), the effectiveness and success of corporate entities have been attributed by their managers to the quality of their human resource. When managers go through the process of human resource accounting measurement which treats human resource as capital, they are more likely to make decisions that treat the companies' employees as long term investments of the company (Bullen and Eyler, 2010)\}. 


\section{Statement of the Problem}

The subsisting general purpose financial statements provide information about the financial position and performance of corporate entities. These accounting numbers are generated from the various value creating activities of the human resource factor. However, while other factors are assigned weight, values and are reflected in the balance sheet or the ultimate statement of financial position, the human resource factor is expensed at the Income Statement level. When the Chairman of a Board of any corporate entity declares to the shareholders at an annual general meeting that the greatest asset of their organization are its people, it is impossible to validate such an assertion with human resource accounting numbers in the financial statements. This is because no values are assigned to human assets as intangible assets. So there is a problem of non-assignment of values to human capital and its exclusion from the elements of annual balance sheet in spite of the fact that it enhances corporate profile, builds goodwill and raises the efficiency of other resources for greater productivity. This is a challenge to the true and fair status as well as the presentational faithfulness of financial statements.

\section{Objective of the study}

The main objective of this study is to determine the implications of human resource accounting in human capital measurement in financial reports. The study will determine the implications of the inclusion of the asset of human capital in the financial statements of corporate entities. The study will also assess the implications of the inclusion of human resource numbers in financial statement on the financial reporting framework in Nigeria.

\section{Research questions}

1. What will be the implication of assigning financial values to human resource through human resource accounting on the assets of the selected banks?

2. How will the assignment of financial values affect company income tax and government's tax revenue?

\section{Methodology:-}

This study will use ex-post facto research design to obtain secondary data from two purposively selected listed money deposit banks-Diamond Bank PLC and Wema Bank PLC- (i.e., their five years audited financial statements) covering the period 2012-2016. The data will be reviewed and compared to determine the implications of capitalising personnel expenses on the assets of the two banks as well as on government tax revenue.

\section{Significance of the study}

Intellectual capital has been described as the hidden value between the market value and book value of an entity (Edvisson and Malone, 1997). The thrust of human resource accounting is to reveal and bring to the fore this hidden value. According to Brummet, Flamholtz and Pye (1969) as cited by Bullen and Eyler (2010), human resource accounting is a tool for increasing managerial effectiveness in the acquisition, development, allocation, maintenance and utilization of its human resources. Thus, except organizations deliberately appreciate the quality of their human resource, they will continue to treat investment in capacity building as a cost to be expensed. This study will therefore seek to bring to the consciousness of managers that the ability of their organisations to demonstrate resilience in the market place, have competitive advantage over their peers and sustain their going concern and future prosperity depend on how their human resource is valued, weighted, managed and rewarded. In line with literature, human resource accounting will make that valuation and assignment of numbers possible. Accordingly, the study will also convey to standard setters and policy makers the need to embrace human resource accounting not only to enhance the presentational faithfulness of financial statements but also to ensure that the statements are true, fair and devoid of hidden values.

\section{Literature Review}

This section provides insight into the Conceptual, Theoretical and Empirical reviews as they relate to the implication of human resource accounting for human capital measurement in financial reports.

\section{Conceptual Review}

The key concepts in this study include human capital accounting, human resource measurement and financial reports. The explanation of these concepts will provide additional information on the thrust of this study.

\section{Human Resource Accounting}

Human resource is primarily a part of the intangible asset of an entity. As an asset, its use is expected to result in an inflow of economic benefits to the entity. Thus, human resource accounting is the science of assigning financial 
values to the man-factor based on cost of acquisition, training and experience. According to Adebawojo, Enyi and Adebawo (2015), the essence of human resource accounting is to establish a generally accepted model of valuation for human asset and ensuring that the value that drives organization for desired performance is adequately represented and disclosed in financial statements as intangible assets.

\section{Human Capital Measurement}

The concept of measurement in accounting has to do with the process of assigning values to an asset, for the first time, such that it can be objectively reflected in the financial statements. One basis for measuring assets is the cost of acquisition approach. Such a cost is included in the book as the historical cost of that asset. Citing Kirfi and Abdullahi (2012), Akintoye(2012) stated that human capital accounting is the process of identifying and reporting the investments made in human resources of an organization that are presently not accounted for in the conventional accounting practice. It involves measuring the costs incurred by the entity to recruit, select, hire, train and develop human capital (Flamholtz, 1974).

However, for intangible asset like human resource which provides services, the concept of measurement needs to be treated in line with International Accounting Standard (IAS) 38. To be considered for measurement, the intangible asset must first satisfy the criteria for recognition which include being identifiable and controlled by the entity. Human resource can be separated, leased, hired, transferred or outsourced (rented out) singly or in combination with other assets. The entity can control human resource to the exclusion of all others through contract engagements and the economic benefits therefrom will flow into the entity. Since human resource satisfies these criteria, it qualifies as an intangible asset and should appropriately be measured in line with the provisions of IAS 38 .

\section{Financial Reports}

These are stewardship reports prepared by persons in fiduciary positions to provide information to their principals. Most of these reports are statutorily required and must be audited to enhance their credibility.

\section{Theoretical Review \\ Human Capital theory}

This theory holds that education and training improve the skills and competences of employees and their ability to earn higher income. In fact, human beings deliberately incur cost of education because of the expectation of a higher earnings capacity after the training. Since the cost incurred in acquiring education is expected to yield higher benefits in the future, it should be treated as investments. The Human Capital Theory was developed by Schultz (1961) and extended by Becker(1964). According to Adebawojo,et al (2015), the theory contends that education or training enhances the productivity of employees by imparting useful knowledge and skills, thus raising workers' future income through increase in life time earnings. Thus, the huge cost of education should be capitalized as investment since it was undertaken with a view to earning higher income. The Becker (1964) perspective introduced the fact that human capital or skills acquired is unique to the individual and not transferable but substitutable. This perspective notwithstanding, since a huge cost is incurred in training, development and medical care to improve future productivity, it should be considered as investment and capitalized.

\section{Resource Based Theory}

The ability of an entity to deliver value to its diverse clientele and enjoy competitive advantage over its peers is a function of the quality of its human resource. Further investment in education, training and development of these employees will increase their competences and productivity. This is the thrust of the Resource-based theory as espoused by Baney (1991). Only employees with unique skills and competences will add value and assist the organization to make the desired difference. Such rare and unique skills and competences should not be such that can be replicated by competitors; otherwise, the expected value will not be created. The underlying factor behind the competitive advantage of a firm is the body of expertise possessed by its employees. The cost of acquiring this level of performance should be capitalized. This study is based on the Resource-based theory.

\section{Accounting Measurement of Human Capital}

According to IAS 38, to be identifiable and subject to the control of an entity is key to the measurement of human capital. Thus, there are three approaches to the accounting measurement of human capital: the cost approach, value approach and monetary approach. (Bontis, 1999; McRae, 1974; Sackmann, Famholtz and Bullen,1989). 


\section{Cost or historical cost model}

Organizations have a pool of human resources to select from when they desire to hire new hands or they can decide to promote from within to fill the vacancy. These costs including those for recruiting, selecting, hiring, orientation, deployment, re-training, learning and loss of performance during training incurred because of the expected service or benefit from the employee. This is similar to the cost associated with procuring a physical asset or other intangible assets from which future benefits are expected to flow into the company. It is the historical acquisition cost. The variants of this cost include, opportunity cost, standard cost, actual cost, job rotation cost and replacement cost. Severance and replacement costs may also be incurred due to labour turnover. The entity should be able to separate the cost that will be expensed as expenditure and that which is to be capitalized. The portion that is consumed in the current year can be expensed whereas the portion that may be expected to generate future benefits in subsequent periods can be classified as asset and capitalized(Andrade\& Sotomayor, 2011; IAS 1). Irrespective of how determined, "the economic value of an active human does not necessarily correspond to its historical cost. Any appreciation or depreciation may be subjective, with no relationship to any increase or decrease in the productivity of human assets (Andrade\& Sotomayor, 2011, p.80)".

\section{Value approach}

The value model was discussed by Flamholtz (1999) in the context of the economic concepts of value in use and exchange value. Value in use refers to the ability of a commodity to satisfy the want of the consumer whereas, exchange value is the purchasing power of the medium of exchange. An asset must satisfy either of the two perspectives to have value to which weights can be assigned. According to Flamholtz (1999), "if an object is not capable of rendering future economic services, it has no value. In these terms, an object's value is typically defined as the present worth of the services it is anticipated to render in the future."Human resources meet the value in use perspective as it stimulates, on continuous basis, efficiency, competitive advantage, greater productivity and profitability. Indeed, reward in any entity is performance driven while the retention of any human capital is a function of the relationship between its cost of retention and the expected benefits.

\section{The Monetary Valuation Model}

This model is based on the accounting practice of discounting future streams of benefits to determine the current value. It is akin to determining the net benefit of an employee to a company. His cost of acquisition is set against the discounted future payments in terms of wages and salaries. With the cost benefit analysis, the entity is able to take decisions concerning how to better manage the personnel for greater productivity.

\section{Empirical Review}

Over time, accounting models have been developed for measuring human capital. These include the Flamholtz model; Hekiman model; Lev and Schwartz model; Hermanson Model; Hicks and Caper model; Likert-Bowers model; Morse and Casio model; and Dobija Model. However, Akintoye(2012) has comprehensively and persuasively discussed the deficiencies of these various models and offered suggestions on the use of a holistic model, called the Human Capital Valuation Model that will capture the peculiar nature of human capital as an intangible asset.

In mathematical terms, the Human Capital Valuation Model can be depicted as:-

$$
\mathrm{Y}=\alpha_{0}+\sigma_{1} \mathrm{HM}+\sigma_{2} \mathrm{DI}+\sigma_{3} \mathrm{JI}+\sigma_{4} \mathrm{RRE}+\sigma_{5} \mathrm{EFF}+\sigma_{6} \mathrm{P}+\mu
$$

With Amortisation rate, the model becomes:-

$$
Y=\alpha_{0}+b_{1}(H M / x)+\sigma_{2}(D I / x)+\sigma_{3}(J I / x)+\sigma_{4}(R R E / x)+\sigma_{5}(E F F / x)+\sigma_{6}(P / x) r+\mu
$$

Where HM= Hiring mode; DI= Development Investment; JI =Job Investment:-

$\alpha=$ constantRRE $=$ Return and Risk; EFF=Efficiency; P=Probability of the individual leaving the firm;

$\mu=$ Error term; $r=$ discount rate external to the organization; $x=$ expected service period

With the above model and using data from three listed companies over 2-year period, Akintoye et al (2016) established that corporate entities that did not include human capital in their balance sheets were most likely to produce misleading reports as those reports show hidden assets. Their analysis confirms the effect of non-reflection of human capital asset in the statement of financial position and recommends a model for appropriate measurement of human capital as intangible asset with an amortisation rate. 
Similarly, using ex-post facto research design, Adebawojo, et al (2015) also established the fact that human capital efficiency has significant relationship with financial performance, return on capital employed and earnings per share(EPS). This finding which is in tandem with Rehma et al (2011) shows that training and development which are strategies for enhancing the human capital efficiency and productivity can be regarded as investments and given appropriate treatment in the books of the entity. In view of the positive impact of training and development on employees' efficiency and corporate performance, the study concluded that the current accounting practice of expensing every expenditure on human assets should be discontinued as the resultant financial statements do not only understate the entity's profits but also do not show a true and fair view.

\section{Methodology:-}

This study obtained ten years secondary data from two listed money deposit banks-Diamond Bank PLC and Wema Bank PLC- (i.e., their five years audited financial statements) covering the period 2012-2016. Their financial statements were reviewed to determine the implications of capitalising personnel expenses on the assets of the banks as well as the impact of expensing same on government tax revenue. The two money deposit banks were purposively selected because they are, respectively, prominent in South East and South West and not among the First Tier banks. In addition, Wema Bank PLC was distressed in 2012 before its rescue whereas, Diamond Bank PLC did not have any such financial challenge.

\section{Data Analysis and Findings:-}

This study was based on the audited statements of financial position and income statements for five years for Diamond Bank PLC and Wema Bank PLC for the period 2012-2016. The data for 2017 for both banks were not ready since their year-end was December 31 in line with the uniform year-end policy of the Central Bank of Nigeria for all money deposit banks. Table 1 contains the abridged financial statements for Diamond Bank PLC while Table 2 contains those of Wema Bank.

Table 1:-Abridged five years financial results of Diamond Bank PLC

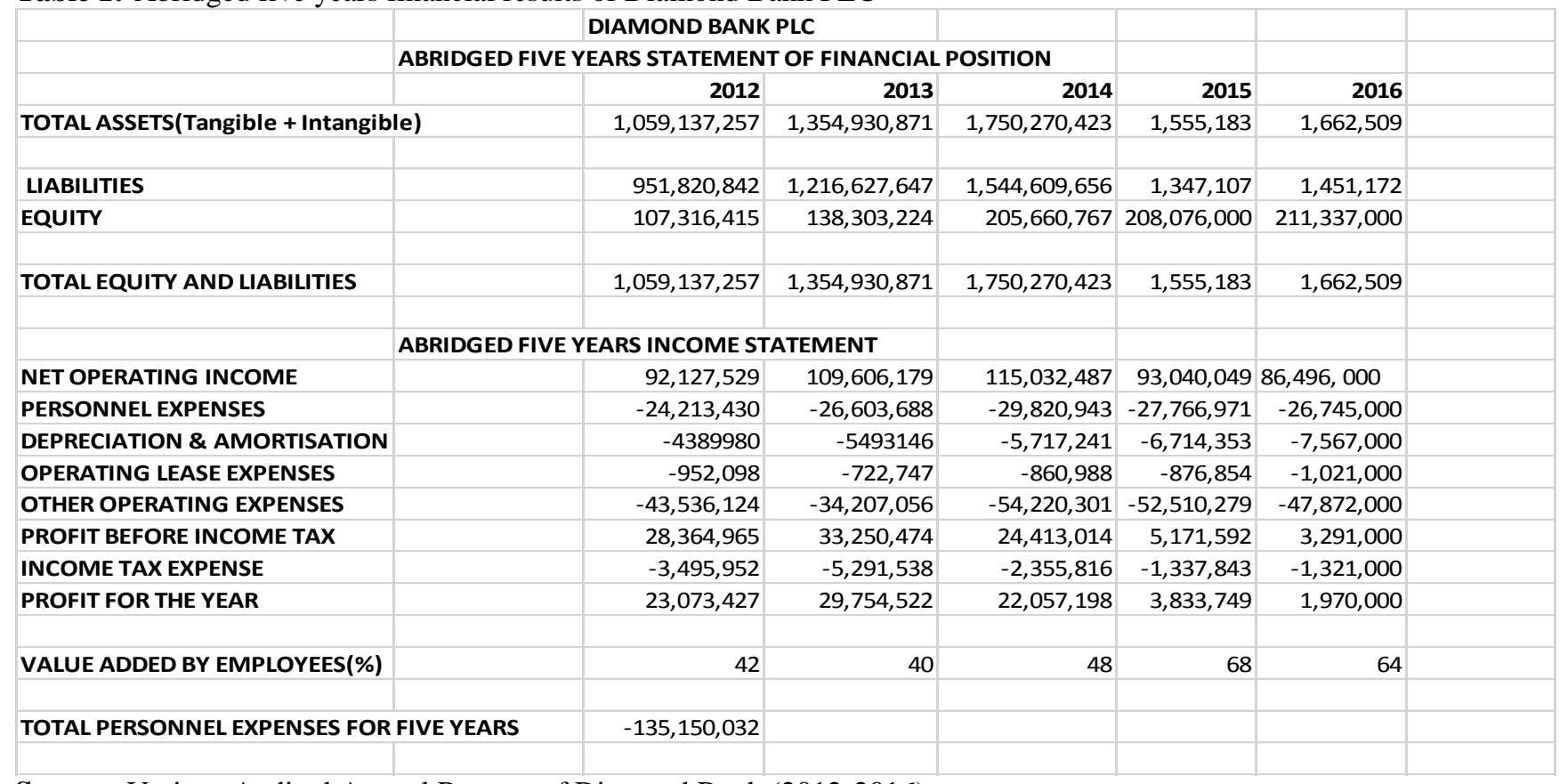

Source:-Various Audited Annual Reports of Diamond Bank (2012-2016)

The financial statements are general purpose and were prepared in line with accounting standards and regulatory requirements. For the five years, the audited accounts for both banks were not qualified by the external auditors who were two of the Big 4 accounting firms. So, they were also approved by the CBN. As required, Personnel expenses were treated as income statement items and expensed in line with IAS 1. In 2012, the Board of Diamond Bank PLC expensed the sum of 24.2 million as personnel expenses which included the cost of training, wages, salaries and 
other benefits. As a result, the assets of the bank for that year were understated by that same amount. The peak of these expenses occurred in 2014 when $\$ 29.8$ m was expensed.

Altogether, for the five years reviewed, the assets of the bank were understated by $\$ 135,150,032$ (that is, the amount of human resource-related expenditure that was expensed) because accounting standards do not accommodate the capitalization of the cost of human resource, which the board claims to be its most important asset.

Given the company income tax rate of $30 \%$, the government "lost" a notional tax revenue of $\$ 40,545,009.6$ for the five years because the subsisting accounting practice does not support the capitalization of human capital expenses. As demonstrated in the literature, the training acquired by human capital improves their efficiency and productivity(Adebawojo, et al, 2015; Akintoye, 2012; Flamholtz, 1974). These expenses should have been treated as investments because the trainings were undertaken in expectation of improved performance and reward.

The understatement of profits, have implications for earnings per share, shareholders' funds and return on assets as demonstrated by Adebawojo et al (2015) and Rehman et al (2011). Accordingly, it is fair to assert the shareholders were not given accurate information about the performance and worth of their bank due to this universal accounting practice of not assigning values to human resource accounting so that it can be reflected as element in the balance sheet.

Furthermore, as indicated in Table 1, the board attributed the value added to the organization and society in those years largely to the employees. The percentage of the value added by Diamond Bank employees ranged between 42 and 68 with a slight decline in 2016 to 66 due to macroeconomic challenges which were not peculiar to Diamond Bank. This is in tandem with the views of Sharma (2012) that the success of any corporate entity is defined by the quality of its people or human assets. In essence, the board acknowledged the role of the employees in value creation but in line with accounting standards, it still expensed the cost associated with such an asset.

Table 2 shows the financial data for Wema Bank PLC for the period 2012-2016 extracted from its audited financial statements as hosted on its website and that of the Nigerian Stock Exchange.

Table 2:-Abridged five years financial statements of Wema Bank PLC(2012-2016)

\begin{tabular}{|c|c|c|c|c|c|c|}
\hline & \multicolumn{3}{|c|}{ WEMA BANK PLC } & & \multirow[b]{3}{*}{2015} & \multirow[b]{3}{*}{2016} \\
\hline & \multicolumn{4}{|c|}{ ABRIDGED FIVE YEARS STATEMENT OF FINANCIAL POSITION } & & \\
\hline & & 2012 & 2013 & 2014 & & \\
\hline \multicolumn{2}{|l|}{ TOTAL ASSETS(Tangible + Intangible) } & $245,704,597$ & $330,872,475$ & $382,562,312$ & $396,743,314$ & $421,221,036$ \\
\hline LIABILITIES & & $244,426,281$ & $289,477,324$ & $338,793,663$ & $350,679,204$ & $372,719,083$ \\
\hline EQUITY & & $1,278,315$ & $41,395,151$ & $43,768,649$ & $46,064,110$ & $48,501,953$ \\
\hline \multirow[t]{2}{*}{ TOTAL EQUITY AND LIABILITIES } & & $245,704,597$ & $330,872,475$ & $382,562,312$ & $396,743,314$ & $421,221,036$ \\
\hline & \multicolumn{3}{|c|}{ ABRIDGED INCOME STATEMENT FOR FIVE YEARS } & & & \\
\hline Operating income & & $12,476,133$ & $20,957,449$ & $25,197,380$ & $26,460,975$ & $28,068,780$ \\
\hline Personnel expenses & & -7831273 & $-8,932,412$ & $-10,032,917$ & $-9,790,477$ & $-10,352,321$ \\
\hline Depreciation and amortization & & -1720274 & $-1,390,814$ & $-2,180,693$ & $-2,250,024$ & $-2,308,498$ \\
\hline Other operating expenses & & -5687991 & $-9,617,341$ & $-9,889,830$ & $-11,374,946$ & $-12,131,597$ \\
\hline Profit before tax & & -4942210 & $1,947,308$ & $3,093,940$ & $3,045,528$ & $3,276,364$ \\
\hline Income tax expense & & $-98,418$ & $-350,777$ & $-721,495$ & $-718,253$ & $-684,565$ \\
\hline Profit for the year & & $-5,040,630$ & $1,596,531$ & $2,372,445$ & $2,327,275$ & $2,591,799$ \\
\hline VALUE-ADDED BY EMPLOYEES(\%) & & 0 & 73 & 66 & 65 & 65 \\
\hline \multicolumn{2}{|c|}{ TOTAL PERSONNEL EXPENSES FOR FIVE YEARS } & & $-46,939,400$ & & & \\
\hline
\end{tabular}

Source:-Various Annual Audited Financial Statements of Wema Bank PLC (2012-2016)

In five years, Wema Bank expensed the sum of $\$ 46.9$ million on personnel expenses in line with accounting standards. At the company income tax rate of $30 \%$, the notional tax revenue lost by the government is 
$\$ 14.07$ million. It is instructive to note that the bank was one of the banks that had liquidity and solvency challenges before the new management took over the bank in 2011.

From a negative profit of $\$ 5$.0million in 2012, the bank declared a positive profit of $\$ 2.6$ million in 2016. This consistent positive performance in the last five years was attributed to the quality of the new personnel. Indeed, the value-added by employees was 73\%, 66\%, 65\% and 65\% for 2013, 2014, 2015 and 2016 respectively. With the loss of $\$ 5.0 \mathrm{~m}$ in 2012 , no value-added was attributed to the employees. This demonstrates that the success of any entity depends on its staff.

As noted above, expensing personnel cost at the income statement level has implications for the value of the total assets of the bank, its earnings per share and return on assets (Adebawojo et al, 2015). In line with accounting practice, if the value of personnel expenses was debited to the total asset to increase it, the credit would have been in the retained earnings. This would have demonstrated that the bank was accumulating funds for the re-skilling or replacement of its intangible asset. How the replacement or reskilling of intangible assets will be financed over time is an issue for planning and strategic thinking.

\section{Summary, Conclusions and Recommendations:-}

Human resource is acknowledged by managers as their most important asset. However, the subsisting general purpose financial statements and generally accepted accounting practices do not accommodate human resource as an element of balance sheet because the costs associated with it are not considered as investments. Literature has affirmed that people acquire education and professional qualifications with a view of enjoying enhanced earnings over time. Similarly, organisations invest in human capacity development not only to improve the performance of their employees but also to sustain their competitive advantage. If their expectation of the training is justified, it is illogical to expense the associated cost which qualifies as a capital expenditure. In line with IAS 38 definition of Intangible Asset, Human Capital qualifies as an intangible asset and should be so recognized. To continue to expense costs associated with human capital development is to present financial statements that are not true and fair. This study recommends that standard setters should develop standards based on the Akintoye(2012) model to permit the inclusion of human capital as an element of the Balance Sheet.

\section{References:-}

1. Adebawojo, O.A., Enyi, P.E. \& Adebawo, O.O.(2015). Human asset accounting and corporate performance. American International Journal of Contemporary Research,5(1), 45-52.

2. Akintoye, I.R. (2012). The relevance of human resource accounting to effective financial reporting. International Journal of Business Management and Economic Resources, 3(4).

3. Akintoye, I.R., Awoniyi, O., Jayeoba, O. \&Olayinka, I. M. (2016). Improvement of human resource accounting disclosure practice in financial statements through IFRS: evidence from Nigerian banks. International Journal of Business and Commerce, 5(7), 1-17

4. Andrade, P. and Sotomayor, A.M. (2011). Human capital accounting-measurement models. International Journal of Economics and Management Sciences, 1(3), 78-89.

5. Barney, J.B. (1991). Firm resources and sustained competitive advantage. Journal of Management, 17, 99-120.

6. Barney, J.B. (1996). The resource-based theory of the firm. Organization Science, 7(5), 469-489

7. Becker, G.S.(1964). Human capital. $2^{\text {nd }}$ Edition. Columbia University Press, New York.

8. Bontis, N.(1999). Managing organisational knowledge by diagnosing intellectual capital: framing and advancing the state of the field. International Journal of Technology Management, 18(5-8), 433-62.

9. Brooking, A. (2010). Management of Intellectual Capital long range planning. Journal Intellectual Capital, 30(35), 364-365.

10. Brooking, A., Board, P. and Jones, S. (1998).The predictive potential of intellectual capital. International Journal of Technology Management, 16(1/2/3), PP 115-125.

11. Bullen, M.L. and Eyler, K. (2010). Human Resource Accounting and International Implications for Measurement of Human Capital. Journal of International Business and Cultural Studies.

12. Edvinsson, L. and Malone, M.S. (1997), Intellectual capital: realizing your company's true value by finding its hidden brainpower. New York: HarperBusiness Press, NY.

13. Flamholtz, E.G.(1973). Human Resource Accounting: measuring positional replacement cost. Human Resource Management, 12. Spring. 
14. Flamholtz, E.G.(1999). Human Resource Accounting-advances in concepts, methods and applications. KluwerPublishers, Boston.

15. Kirfi, M. and Aminu, A. (2012). Human capital accounting: assessing possibilities for domesticating practice in Nigeria. Research Journal of Finance and Accounting, 3(10), 57-63.

16. Lev, B. (1997). The old rules no longer apply. Forbes, 7 April.

17. McGregor, D. (1960). The Human side of enterprise. New York: McGraw-Hill

18. McRae, T.W. (1974). Human resource accounting as a management tool. Journal of Accounting, USA, 32.

19. Oke, O. (2010). Transforming human capital potentials into organisation capability. Journal of Professional Administration, 37-41.

20. Rehman, W.U., Rehman, C.A., Rehuman, H.U. and Zaliad, A. (2011). Intellectual Capital performance and its implications on corporate performance: An empirical evidence from modaraba sector of Pakistan. Australian Journal of Business and Management Research, 1(5), 8-16.

21. Roos, J., Roos, G., Dragonetti, N. and Edvinsson, L. (1997), Intellectual Capital. Macmillan Business, New York, NY.

22. Sackmann, S., Flamholtz, E. and Bullen, M. (1989). Human resource accounting: a state-of-the-art review. Journal of Accounting Literature, 8, 235-64.

23. Schultz, T.W.(1961). Investment in human capital. The American Economic Review, 1(2), 1-17.

24. Sharma, A. (2012). Impact of human resource accounting on organization performance. IOSR Journal of Business and Management (IOSR-JBM), 5(1), 25-31. 